\title{
Designing and Developing Interactive Learning Multimedia Using 3D Game Engine
}

\author{
Basuki Heri Winarno \\ Program S2 Magister Teknik Informatika, STMIK AMIKOM Yogyakarta \\ Ring Road Utara, Condong Catur, Depok, Sleman, Yogyakarta, Indonesia \\ Email: bheriwinarno@gmail.com
}

\begin{abstract}
Abstrak. Penelitian ini secara umum difokuskan pada proses perancangan dan pengembangan media pembelajaran interaktif menggunakan Unreal Development Kit, yang dalam hal ini terdiri dari tiga bagian utama yaitu: mendesain objek $3 D$, mendesain objek $2 D$ untuk dipakai sebagai UI, dan menyusun semuanya menjadi sebuah level dalam UDK. Tahap berikutnya adalah mengujikan media pembelajaran ini pada sejumlah subjek dan meminta mereka mengisi kuesioner untuk mengetahui minat dan tanggapan mereka terhadap media pembelajaran tersebut. Subjek penelitian terdiri dari 14 siswa kelas 9 yang dipilih secara acak dengan usia antara 14-15 tahun. Hasil penelitian menunjukkan bahwa: (1) Hampir semua subjek memberikan tanggapan positif terhadap media pembelajaran ini; (2) Media pembelajaran ini memperoleh nilai 76,9 dan 64,2 oleh ahli media dan ahli materi yang dalam hal ini berarti valid; dan (3) Semua subjek berminat menggunakan media pembelajaran ini di perangkat mobile.
\end{abstract}

Kata Kunci: $3 D$ Game Engine, UDK (Unreal Development Kit), media pembelajaran interaktif, sekolah menengah pertama

\begin{abstract}
This study mainly focuses on the process of designing and developing interactive learning media by using Unreal Development Kit, which basically consists of three main parts, i.e., designing $3 D$ objects, designing $2 D$ objects to be used as UI (User Interface), and arranging them into a level in UDK. The next stage is having subjects to test the level and fill out a questionnaire to find out their interest and response towards the use of this new type of learning media. The subjects are randomly-picked, they are 14 ninth-grade students from several junior high schools aged 14 to 15 years old. The results show that: (1) almost all subjects give positive response towards this type of learning media; (2) this new leaning media is rated 76.9 and 64,2 by media and material experts consecutively, meaning that the media is valid to be used; and (3) all subjects would like to use this media in mobile platforms.
\end{abstract}

Keywords: 3D Game Engine, UDK (Unreal Development Kit), Interactive Learning Media, Junior High School

\section{Introduction}

The advance of information technology has brought about changes in almost every aspect of human life, including education and learning. One of the recent trends emerging from this fact is the proliferation of interactive learning multimedia, including educational games, for almost any level of education, from preschool children to college students (Ellis, 2006). This trend is driven most by the role played by Adobe Flash (formerly Macromedia Flash), a 2D multimedia platform capable of integrating video, animation, and interactivity into an attractive package playable in either web browser or as a standalone application. Recent trends in the development of multimedia-based learning system also incorporate the use of $3 \mathrm{D}$ objects to create a more interesting flash presentation.

Meanwhile, another recent trend that had been waited for so long by some has finally come, that is the availability of 3D game engines for personal use. As late as 7 or 5 years ago, if 
someone wanted to make games or interactive contents in $3 \mathrm{D}$, he had no choice other than built it from scratch (using available programming languages, mostly $\mathrm{C}++$ ) or spent hundreds to thousands of dollars to get a license for a ready-made engine with no guarantee whatsoever that his game would be a hit. For example, in 2003 it was reported that the license cost for Unreal Engine was as much as US\$ 350,000 (Shiratuddin, 2003).

Unreal Engine 3, as one of the best game engine available today, gives a surprisingly interesting offer by releasing UDK (SDK version of UE3) in 2009 for public use for free. Epic Games, the creator of Unreal Engine only asks $\$ 99$ for the commercial license.

\subsection{Purpose}

Based on the above description, the purpose of this research paper is to explore the possibility of designing and developing an interactive learning multimedia using UDK, therefore pushing the multimedia-based learning system to another level by integrating the power of Flash-based presentation and 3D contents into a real time interactive visualization.

\subsection{Research Questions}

This research was motivated by the following questions (1) How can we take interactive learning multimedia to a higher level by presenting it in a full 3D environment in which subjects can roam and actively involved in the learning process? (2) How do they respond to this new learning media and are they interested in using this learning media in platforms other than PC?

\subsection{Research Limitations}

Research Limitations can be described as follows: (1) There will be only one simple level made in UDK, because the process of making a big or even huge level in a game is the same as making a simple level. (2) This research takes on the subject of Physics for the ninth grade Junior High School students based on the 2006 curriculum. (3) The topics that will be covered are about Earth, i.e., Internal Structure of the Earth, Earth's Atmosphere, Earth's Magnetosphere, Continental Drift, and Earth as a planet in the Solar System.

\subsection{Methodology}

The method employed for this research is research and development. This method is implemented to create a specific product and examine its effectiveness. This research adopted a method adapted from Borg and Gall consisting of six developmental steps, namely: analytic, design, development, validation, revision, and testing. (Depdiknas, 2008) (Sumarno, 2012).

(1) Analysis. In this stage, information concerning the design and development of learning multimedia are gathered and analyzed, including analysis on needs assessment as suggested by Lee (1991). (2) Design. This stage concerns with deciding what aspects should be implemented in the project based on instructional design by Lee (2004), creating several drafts for 2D interface, 3D models, and the level itself. (3) Development. This stage consists of creating the preliminary objects to be tested at the next stage. These objects are 2D flash file (*.swf files), 3D models (*.fbx files), and a UDK level. (4) Validation. This stage is meant to find out the evaluations given by the media and material experts. (5) Revision. This stage examines the validations and recommendations by the experts, and then implements them in the project. (6) Testing. The product is then tested to find out the students' response towards this new type of interactive learning media.

\subsection{Data Analysis}

The data gathered from validations by media and material experts as well as from the subjects are evaluated to find out its importance in relation with the questions of this research. In general, the process of data analysis is: validation data from media expert, material expert and students' response are calculated using rating scale and then compared with the ideal value to determine its feasibility. 


\section{Discussions}

\subsection{Review of Literature}

Multimedia, in computer science, is a presentation of information using the combination of text, sound, pictures, animation, and video. Common multimedia computer applications include games, learning software, and reference materials (Ditto, 2009). The similar view is also expressed by Suyanto (2003) with several additions included in his later book about multimedia and competitive edge (Suyanto, 2009).

Interactive media is the integration of digital media including combinations of electronic text, graphics, moving images, and sound, into a structured digital computerized environment that allows people to interact with the data for appropriate purposes. The digital environment can include the Internet, telecoms, and interactive digital television. (England, 2011).

Game Engine is a system designed to develop and build video games, which usually includes a complete framework consisting of several elements such as render engine, physics engine, audio engine, programming, animation, AI, networking etc. Most of modern game engines are based on the concept explained in Zerbst (2004). Lewis (2002) elucidated aspects concerning the use of game engines in Scientific Research.

\subsection{Previous Research}

Some of the references implied in this research are as follows. Ellis (2006) discussed the possibilities of using video games in learning environments as well as the difficulties in creating an interesting game-based learning media. Sanford (2005) discussed the increasing interest towards games as educational media all around the world. Muller (2006) talked about a growing number of educational institutions that integrate technology in their teaching-learning environments. Papastergiou (2007) discussed the effectiveness of using game in a high school curriculum as opposed to the use of non-game learning application. Shutterland (2008) discussed the implementation of game "Second Life" as a learning media. "Second Life" is an online MMORPG developed by Paisley University. Trenholme (2008) created a fire-fighting fighting simulation for high school students using "Source" game engine from Valve Corporation. Smith (2009) discussed the process of prototyping a virtual fire drill environment, also using "Source" game engine.

Concerning the use of Unreal Engine and UDK, the following researches were used as references. Shirattudin (2003) created a virtual office using game "Unreal Tournament", but mainly emphasized on the technical aspects of the process. Burger (2013) created an interactive architectural visualization using UDK and tested it to a number of respondents. Schroeder (2011) in his master thesis also discussed the use of game technology (UDK) for architectural visualization.

\subsection{Hardware Requirements}

For content development, UDK recommends a personal computer with the following system configuration (based on the specifications listed in UDN.com): Windows Vista 64 SP2; 2.0+ GHz multi-core processor; 8 GB system RAM; NVIDIA 8000 series or higher graphics card; Plenty of HDD space.

\subsection{Software Requirements}

In order to create interactive learning multimedia using game engine $3 \mathrm{D}$, several software are needed: (1) 3D modeling and animation (3DS Max, Maya, Blender, etc.). This research used 3DS Max 2009; (2) 2D authoring and animation software (Adobe Flash, Flash Develop, etc.). This Research used Adobe Flash CS3; (3) Unreal Development Kit, this research used March 2011 edition, downloaded from www.unrealengine.com/en/resources/.

\subsection{Design and Development}

The research object is a virtual-futuristic 3D room with several objects placed inside it 
with which player can interact. This room is fairly simple with two sections separated with an automatic door. The room consists of several basic objects (mainly in the form of a box) with a few variations such as raised and lowered platforms connected with stairs. Another variation is that there will be 2 floors, but the second floor is not accessible by the player and only serves to make it look more grandeur. To give an impression that this is just a part of a bigger virtual world, there are several doors in this room, even though these doors are not accessible by the player either.

There are five objects in this room which the player can interact with, three of which consist of 3D models and flash files as for the explanation, one object does not include a 3D model but uses two flash files, while the last object contains a virtual monitor in which students can view several video footages about Earth as a planet and Earth in the Solar System. These objects represents different subtopics based on the main topic selected in this research, i.e., about Earth. In this case, the subtopics are: Internal Structure of the Earth, Earth's Atmosphere, Earth's Magnetosphere, Continental Drift, and Earth as a planet in the Solar System.

\subsection{Modeling}

The modeling process in this research is accomplished using 3DS Max 2009. All 3D models in this research use diffuse map and normal map. Diffuse map is a texture (or image) that is used to define a surface (or object's) main color. In general, the modeling process is described in Figure 1.

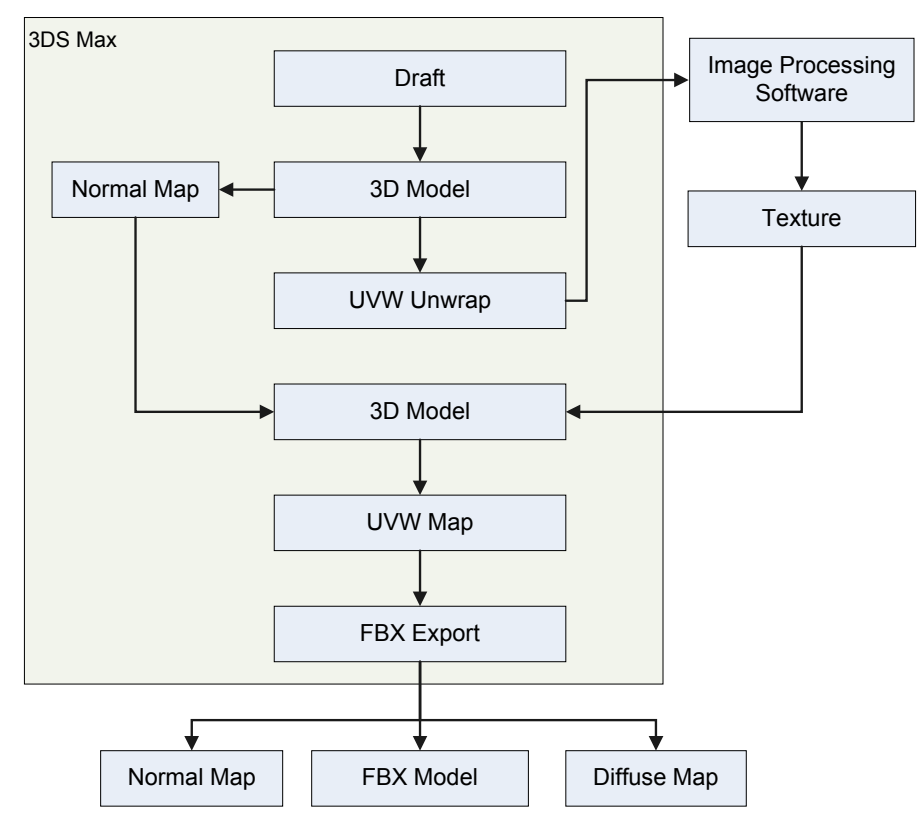

Figure 1. The Process of Creating Models in 3DS Max

The process of creating normal maps represents an important aspect of game-world creation since almost all modern games use this technique. Normal mapping or sometimes called bump mapping is a technique to make a low-poly model look more like a detailed model with high number of polygons and is especially useful in making complex scenes either indoor (as in this research) or outdoor scene. UDK support the use of normal maps in creating materials.

\subsection{User Interface Design}

Unreal Development Kit uses Scaleform GFx (a middleware from Autodesk) to display 2D animations from Flash file in 3D environment, either as HUD (Heads Up Display) or as a texture (material) of a 3D object (Mooney, 2012).

This research uses 7 UI objects as follows: one UI object for the main menu, one UI 
object containing instruction on how to move the player using WASD keys and mouse, one UI object for the main door containing several vector animations, and four UI Objects for animations and descriptions of Internal Structure of the Earth, Earth's Atmosphere, Earth's Magnetosphere, and Continental Drift.

The process of creating Flash objects to be used in UDK is presented in Figure 2, while the process of importing Flash objects into UDK and setting them up for use as UI is presented in Figure 3.

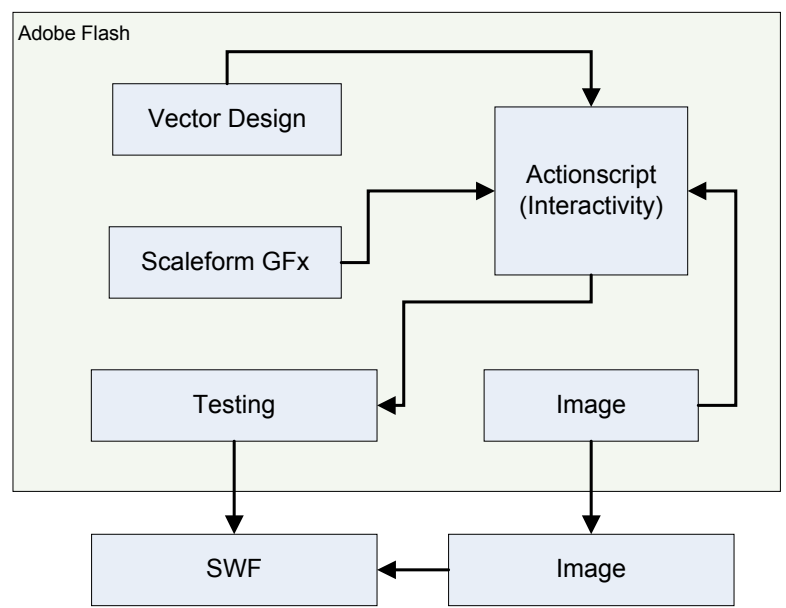

Figure 2. UI Design Workflow in Adobe Flash

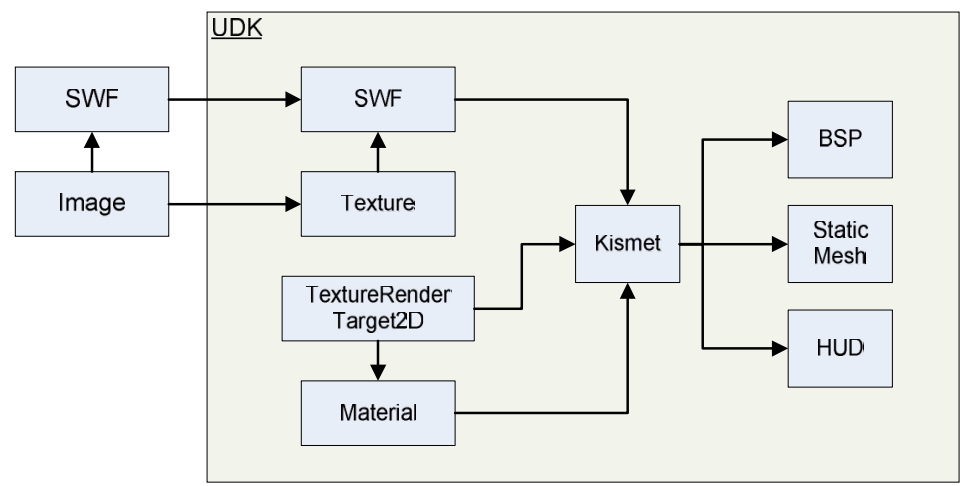

Figure 3. Workflow for creating Flash Asset in UDK

\subsection{Level Creation in UDK}

Level creation in UDK refers to the process of setting up all needed objects in the UDK Editor. This research used workflows for creating a level based on the detailed explanations on introductory level design using UE3 in Busby (2007) and advanced level design using UE3 in Busby (2009). The level creation process in this research also used reference on using UDK in a small team environment as explained in Guldbrandsen (2010). In general, this process can be divided into 3 parts: (1) The process of importing files to be used in the project as Assets in UDK and then grouping them according to its type (meshes, materials, UI, etc.). (2) The process of building a level in UDK Editor which includes setting up static 3D objects (or unmovable objects such as walls, tree, etc.) and creation of BSP objects (or standard objects in UDK, such as box, sphere, plane, etc.). (3) The process of adding interactivities using Unreal Kismet (a visual programming feature in UDK), Unreal Script (UDK scripting language), and Unreal Matinee (animation tool in UDK which can be used to create animation in the game or cinematic sequence) as explained in Mooney (2012).

Figure 4 describes the typical workflow for creating a level in UDK, including the process of importing files from Adobe Flash and 3DS Max. 


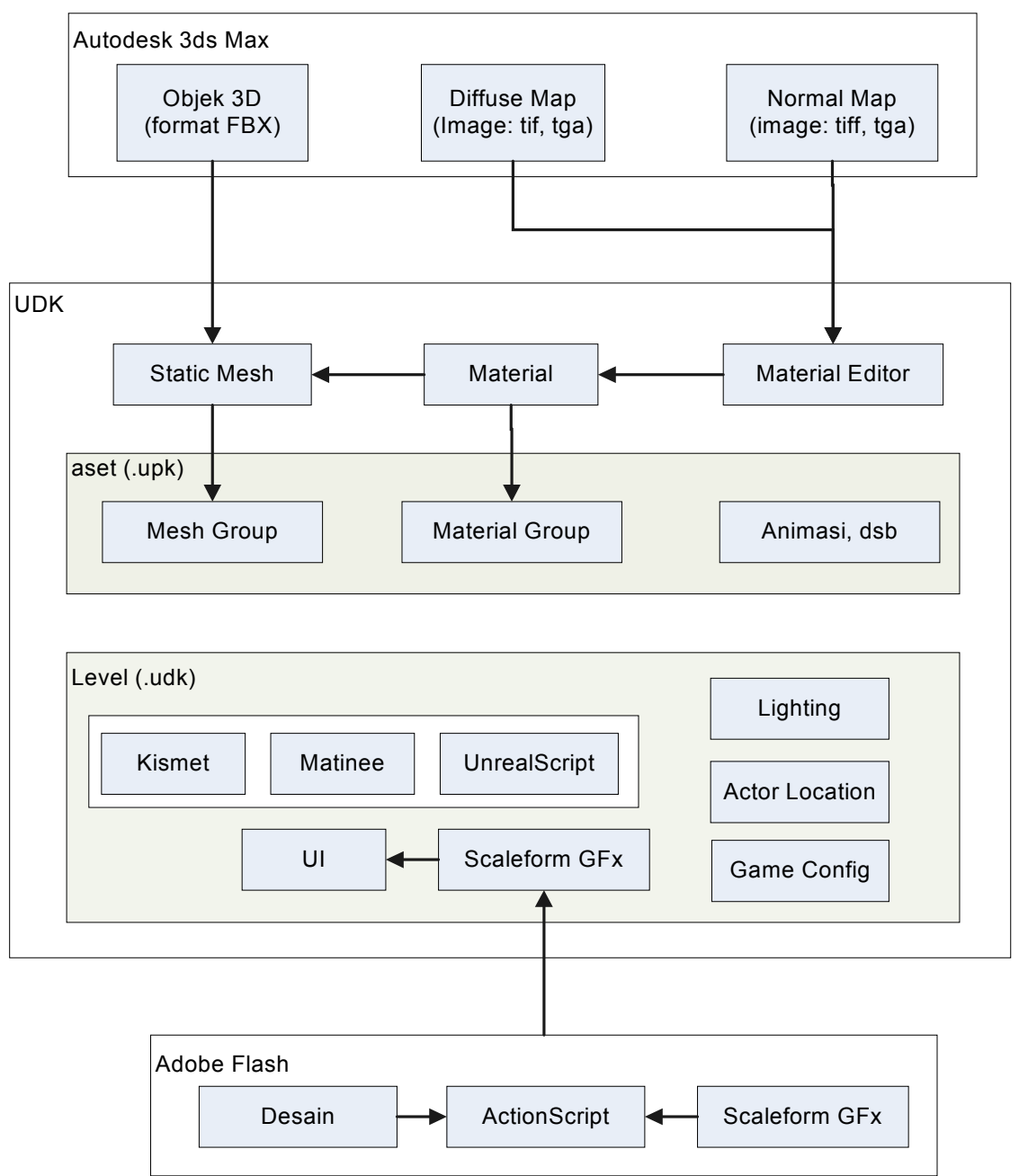

Figure 4. Level Creation Workflow in UDK

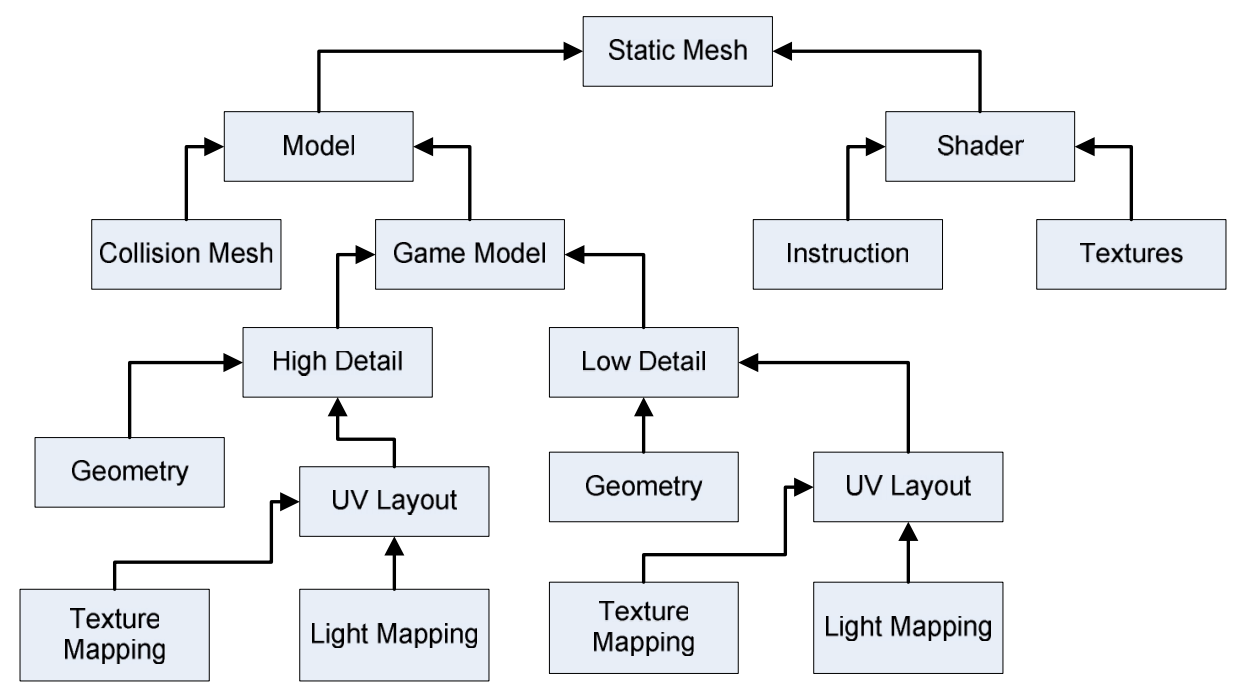

Figure. 5 Basic Workflow for Creating Static Mesh

Another process that was deemed important in creating a level in UDK, and also in many other game engines, is the creation of static objects (static mesh). A static mesh is a piece of geometry (object) that consists of a set of polygons to be rendered by graphic card. Static 
mesh is also the basic unit used to create world objects in Unreal Development Kit. This type of object can range from a plain wall to a seemingly complicated decoration as commonly used in many 3D games. In general, the basic workflow for creating a static mesh is presented in Figure 5 , adopted from Burger (2013).

\subsection{Research Design}

This research uses qualitative study to determine participants' response towards this type of learning media using model described in Stacey (2003). The data are collected from the results of validation tests by media and material experts, as well as questionnaire data from a group of participants consisting of 14 ninth grade students.

To determine the participants' response they were first asked to do five tasks, i.e., (1) Open the application (learning media) and move the character according to the descriptions given in the UI, that is, using mouse and WASD keys on keyboard; (2) Move the character to the main door and press the "E" key to open the door; (3) Move the character to the left side of the room and observe the descriptions given in the UI about Earth's Internal Structure and Earth's Atmosphere; (4) Move the character to the right side of the room and observe the descriptions given in the UI about Continental Drift and Earth's Magnetosphere; (5) Move the character to the center of the room and observe video footages on Earth as a planet and Solar System.

Having finished the tasks, the participants were asked to fill out a questionnaire while still observing the media to clarify the questions in the questionnaire. This research uses 5 notebooks with following specifications: Windows 7 32bit, Intel i5 - 2410M @ 2.30GHz, 4096 RAM, Intel HD Graphics, 500 GB WD Scorpio Blue, @ 1366 x 768, and two desktops with following specifications: Windows 7 32bit, Intel i5 - $3470 @ 3.60 \mathrm{GHz}, 4096 \mathrm{RAM}$, Radeon 5670,1TB HDD, @ $1366 \times 768$.

\section{Data Analysis}

This research uses questionnaires to measure participants' response towards the new interactive learning multimedia using $3 \mathrm{D}$ game engine, and also to gain validations from media and material experts.

\subsection{Media Validation}

The media validation data is obtained from a media expert, which includes assessments of: (1) The conformity between 3D design and objects (including the overall level design) with the chosen topic; (2) The techniques used in designing 2D elements; (3) The techniques used in designing 3D elements; (4) Color composition and lighting; (5) Attractiveness of the 2D animations and effects; (6) Attractiveness of the 3D animations and effects; (7) Attractiveness of the overall level (room) design; (8) The use of mouse and WASD keys to control the character; (9) Sound effects; (10) Whether the topic chosen is easy to understand; (11) Whether this type of interactive learning media is appropriate in autonomous learning; (12) Overall ease of use; and (13) Whether the interactivity is easy to understand. Using Likert scale, it was determined that the media expert assessment reached 76,9 points, and based on the success rate criteria by Arikunto (2006), this value is assumed as valid.

\subsection{Material Validation}

The material validation data is obtained from a material expert, which includes assessments of: (1) Material chosen; (2) The entirety of material; (3) The appropriateness of the language used; (4) Whether the material is easy to understand using this media; (5) Whether this media will be able to motivate students to study more; (6) The effectiveness of this media in delivering the material to students; and (7) The attractiveness of the material. Using Likert scale, it was determined that the material expert assessment reached 64,2 points, and again, based on the success rate criteria by Arikunto (2006), this value is assumed as valid. 


\subsection{Participants' Response}

Having tried the interactive learning multimedia developed in this research for approximately 20 minutes, the participants were asked to fill out a questionnaire to find out their response. There are 15 items in the questionnaire, 12 items are meant to measure their response towards this interactive learning media while 3 other items are meant as follow-up questions to find out the possibility of further development of this interactive learning media.

The first 12 questions are whether: (1) This interactive learning media is interesting as a whole; (2) This interactive learning media will help students to better understand the topic; (3) Animations and descriptions about Inner Structure of the Earth are interesting and easy to understand; (4) Animations and descriptions about Earth's Atmosphere are interesting and easy to understand; (5) Animations and descriptions about Continental Drift are interesting and easy to understand; (6) Animations and descriptions about Earth's Magnetosphere are interesting and easy to understand; (7) The video footages in this learning media are interesting and easy to understand; (8) This interactive learning media is easy to operate; (9) The room or level design is easy to navigate; (10) The character (player) is easy to control; (11) Interactivity of this learning media is easy to understand; (12) Room design and animations as a whole is interesting.

Meanwhile, three follow-up questions are whether: (1) Game elements (i.e., enemies, puzzles, etc.) in this interactive learning media should be added; (2) This interactive learning media should give students some type of tasks to do, for example answering questions concerning with the topics covered; (3) The students would like to see this interactive learning media played on handheld devices and tablet PCs.

From the data analysis, it was concluded that the percentage of participants' response reached $79 \%$ which is categorized as valid. There are several notable results concerning with their response, for example, 94\% participants stated that the descriptions and animations of Earth's Magnetosphere and Continental Drift are interesting while only $66 \%$ of them stated that the animations and descriptions of Earth's Atmosphere is interesting. For the elements of 3D designs i.e., room design and the ease to navigate, $75 \%$ and $78 \%$ of them considered so, consecutively.

For the follow-up questions, $98 \%$ of the participants wanted to see this interactive learning media played on handheld devices and tablet PCs, while concerning with whether this interactive learning media should have game elements and tasks (item \#1 and \#2), the participants' response are favorable, i.e., $71 \%$ and $87 \%$ consecutively.

\section{Conclusions and Suggestions \\ 4.1 Conclusions}

From the process of designing and developing this interactive learning multimedia using 3D game engine (in this case, UDK), it can be concluded that: (1) Game engines are capable of not only creating games but also of creating other real-time visualizations for architectural sites, military simulations, or museums (as have been done in several researches), and also for the field of education, as in this research. (2) Unreal Development Kit has all features needed to create an interactive learning multimedia which combines the power of $3 \mathrm{D}$ visualization, interactivity of Flash-based applications, and superb real-time rendering capability. (3) Interactive Learning Multimedia created using game engine 3D (UDK) in this research has proven to be valid from several testing, i.e., media validation $(76.9 \%)$, material validation (64.2\%), and participants' response (79\%). (4) In general, participants show favorable response towards this type of leaning media, and in the follow-up questions, almost all (13 of 14) participants want to see this type of learning media playable in handheld devices and tablet PCs.

\subsection{Suggestions}

(1) As mentioned in the conclusion, that almost all participants want to see this type of learning media playable in handheld devices and tablet PCs, then the reasonable suggestion is to develop this learning media on mobile platforms, especially Android platform which has 
become a trend nowadays. (2) This research is only a prototype, meaning that it builds a room with 5 interactive objects with which the participants can interact with, and that the participants virtually just walk around the room, observing objects and animations presented. From the follow-up questions, most participants want to see game elements in this application, such as enemies, puzzles, tasks, etc. Therefore, future research might as well include game elements in this type of learning media; so that students can actually "learning by playing" (3) This research uses Unreal Development Kit from Epic Games. In several forums on the net, many mention a game engine with better rendering quality (but with higher hardware requirements), that is CryEngine from Crytek GMBH, which makes it a good candidate for future research on the use of game engine in educational context. Also, there is a free open-source game engine with a relatively good rendering capability, i.e., Nebula Engine (used to create "Drakensang" series) even though its documentation is rather hard to come by.

\section{Bibliography}

Arikunto, S. 2006. Prosedur Penelitian: Suatu Pendekatan Praktek. Jakarta: PT. Rineka Cipta.

Burger, N. 2013. Realtime Interactive Architectural Visualization using Unreal Engine 3.5. Department 'Institut für Informatik', Ludwig-Maximilians-Universität München.

Busby, J., Parrish, Z., Wilson, J. 2007. Mastering Unreal Technology, Volume I: Introduction to Level Design with Unreal Engine 3. Sams Publishing, Indianapolis, Indiana 46240 USA.

Busby, J., Parrish, Z., Wilson, J. 2009. Mastering Unreal Technology, Volume II: Advanced Level Design Concepts with Unreal Engine 3. Sams Publishing, Indianapolis, Indiana 46240 USA.

Depdiknas. 2008. Panduan Pengembangan Bahan Ajar. Jakarta, Depdiknas.

Ditto, W. 2008. Multimedia, Microsoft ${ }^{\circledR}$ Encarta ${ }^{\circledR}$. Redmond, WA: Microsoft Corporation.

Ellis, H., Heppel. S., Kirriemuir, J., Krotoski, A., McFarlane, A. 2006. Unlimited Learning: Computer and Video Games in the Learning Landscape, (Online), (http://www.org.id.tue.n1/IFIP-TC14/documents/ELSPA-report-2006, diakses 13 Februari 2013)

England, E., Finney A. 2011. Interactive Media - What's That? Who's Involved?. ATSF White Paper, ATSF, UK.

Guldbrandsen, K., Storstein, K. 2010. Evolutionary Game Prototyping using the Unreal Development Kit. Norwegian University of Science and Technology, Department of Computer and Information Science, Trodheim, Norway.

Lee, William W., Owens, Diana L. 2004. Multimedia-based Instructional Design: Computerbased Training, Web-based Training, Distance Broadcast Training, Performance-Based Solutions. Michigan: John Wiley and Sons.

Lee, William W., Roadman, Kenneth H. 1991. Linking Needs Assessment to Performance-based Evaluation. Wiley Periodicals, Inc., A Wiley Company.

Lewis, M., Jacobson, J. 2002. Game Engines in Scientific Research. Communications of the ACM.

Mooney, T. 2012. Unreal Development Kit Game Design Cookbook. Packt Publishing Ltd., Birmingham B3 2PB, UK.

Muller, D.A., Eklund, J., Sharma, M.D. 2006. The Future of Multimedia Learning. Sydney University Physics Education Research group, School of Physics, University of Sidney.

Papastergiou, M. 2009. Digital Game-Based Learning in High School Computer Science Education: Impact on Educational Effectiveness and Student Motivation. Department of Physical Education and Sport Science, University of Thessaly, Karyes, 42100 Trikala, Greece.

Sanford, R., Williamson, B. 2005. Games and Learning. Futurelabs, (Online), (http://archive.futurelab.org.uk/resources/publications-reportsarticles/handbooks/Handbook133, diakses 20 Juni 2013)

Schroeder, Scott A. 2011. Adopting Game Technology for Architectural Visualization. Department of Computer Graphics Technology, Purdue e-Pubs, Purdue University. 
Shiratuddin, M., F., Thabet, W. 2003. Virtual Office Walkthrough Using a 3D Game Engine. Virginia Tech, Department of Building Construction, Virginia Polytechnic Institute and State University.

Smith, Shamus P., Trenholme, D. 2009. Rapid Prototyping a Virtual Drill Environment Using Computer Game Technology. Durham University, Durham DH1 3LE, United Kingdom.

Stacey, M., Earl, C., Eckert, C., O’Donovan, B. 2003. A Methodology for Comparing Design Processes. International Conference on Engineering Design, Stockholm.

Sumarno, A. 10 Maret 2012. Pengembangan Multimedia Pembelajaran Interaktif Model Drill And Practice Pada Materi Pengolah Angka Siswa SMP, (Online), (http://elearning.unesa.ac.id/myblog/alim-sumarno/pengembangan-multimediapembelajaran-interaktif-model-drill-and-practice-pada-materi-pengolah-angka-siswa-smp, diakses 10 Januari 2013)

Sutherland, John N., Connolly, T., Livingstone, Daniel J. 2008. How Can We Build Successful $3 D$ Games for Learning?. Department of Computing University of Paisley, Scotland, United Kingdom.

Suyanto, M. 2003. Multimedia: Alat untuk Meningkatkan Keunggulan Bersaing. Andi Offset, Yogyakarta.

Suyanto, M. 2009. Analisis \& Desain Aplikasi Multimedia Untuk Pemasaran. Yogyakarta, Penerbit Andi.

Trenholme, D., Smiths, S., P. 2008. Computer Game Engines for Developing First-Person Virtual Environments. Durham Research Online, Durham University, Durham DH1 3LE. United Kingdom.

Zerbst, S., Duvel, O. 2004. 3D Game Engine Programming. Course Technology PTR. 